\title{
Clinical Significance
}

National Cancer Institute

\section{Source}

National Cancer Institute. Clinical Significance. NCI Thesaurus. Code C82562.

A finding that has treatment or management implications for a patient's condition. 